\title{
Effect of static magnetic field and/or cadmium in the antioxidant enzymes activity in rat heart and skeletal muscle
}

\author{
Salem Amara ${ }^{1,2,3}$, Catherine Garrel ${ }^{2}$, Alain Favier ${ }^{2,3}$, Khémais Ben Rhouma ${ }^{1}$, Mohsen Sakly $^{1}$ \\ and Hafedh Abdelmelek ${ }^{1}$ \\ ${ }^{1}$ Laboratoire de Physiologie Intégrée, Faculté des Sciences de Bizerte, 7021 Jarzouna, Tunisia; E-mail: amara_salem_fsb@yahoo.fr \\ ${ }^{2}$ Laboratoire de Stress Oxydant, Département de Biologie Intégrée, CHU, Grenoble, France \\ ${ }^{3}$ Commissariat d'Energie Atomique DRFMC/SCIB, Laboratoire des Lésions des Acides Nucléiques, Grenoble, France
}

\begin{abstract}
Currently, environmental and industrial pollution along with increase and causes multiple stress conditions, the combined exposure to magnetic field and other toxic agents is recognised as an important research area, with a view to better protecting human health against their probable unfavourable effects. In the present study, we investigated the effect of co-exposure to static magnetic field (SMF) and cadmium (Cd) on the antioxidant enzymes activity and the malondialdehyde (MDA) concentration in rat skeletal and cardiac muscles. The exposure of rats to SMF (128 mT, $1 \mathrm{~h} /$ day during 30 consecutive days) decreased the activities of glutathione peroxidase (GPx) and the superoxide dismutase (CuZn-SOD) in heart muscle. Sub-chronic exposure to SMF increased the MDA concentration in rat cardiac muscle. $\mathrm{Cd}$ treatment $\left(\mathrm{CdCl}_{2}, 40 \mathrm{mg} / \mathrm{l}\right.$, per os $)$ during 4 weeks decreased the activities of catalase (CAT) in skeletal muscle and the CuZn-SOD in the heart. Moreover, $\mathrm{Cd}$ administration increased MDA concentration in the both structures. The combined effect of SMF (128 mT, $1 \mathrm{~h} /$ day during 30 consecutive days) and $\mathrm{Cd}(40 \mathrm{mg} / \mathrm{l}$, per os) disrupt the antioxidant enzymes activity in rat skeletal and cardiac muscles. Moreover, we noted a huge increase in MDA concentration in the heart and skeletal muscle compared to control group. Thus it is possible that the SMF- and/or Cd-induced depletion of antioxidant enzymes activity in muscle tissues might, like the enhanced lipid peroxidation, importantly contribute to oxidative damage.

The combined effect of SMF and Cd altered significantly the antioxidant enzymatic capacity and induced lipid peroxidation in both skeletal and cardiac muscle.
\end{abstract}

Key words: Static magnetic field - Cadmium - Oxidative stress - Muscle - Rat

\section{Introduction}

Biological systems could be simultaneously exposed to many various chemical and physical agents in the natural as well as in the occupational environment. Many factors in our environment cause concern with regard to their biological effects and possible health risks. These risk factors are usually studied individually for their biological effects. In practice, under environmental conditions, they usually act together. It is therefore necessary to examine the effect of combination of the individual pollutants. Among

Correspondence to: Salem Amara, Laboratoire de Physiologie Intégrée, Faculté des Sciences de Bizerte, 7021 Jarzouna, Tunisia E-mail: amara_salem_fsb@yahoo.fr the environmental risk factors that affect human health, magnetic fields (MF) play an important role because of the possible association with childhood malignancy, especially leukaemia but also cancer, cardiovascular, neurological and psychological diseases in adults (Wertheimer and Leeper 1979; Loomis and Savitz 1990; Håkansson et al. 2003; Davanipour et al. 2007). Biological systems can respond to a wide range of static magnetic field (SMF). Some of these responses seem to be mediated partly through free radical reactions leading to oxidative damage (Okano 2008). Heavy metals are too well-known environmental pollutants of particularly dangerous effect to human health, especially since the industrial revolution. One of the most harmful heavy metals, widely spread in nature is $\mathrm{Cd}$ (Boguszewska et al. 2004). Cd is a major environmental pollutant and is 
known for its wide toxic manifestations (Renugadevi and Prabu 2009). Cd contamination of environment is a subject of serious international concern since the metal is known to enter the food chain and can undergo bioaccumulation, endangering human health (Roccheri et al. 2004). The molecular mechanism responsible for toxic effects of $\mathrm{Cd}$ is far from being completely understood. A number of mechanisms of Cd toxicity have been suggested, including oxidative stress (Hussain et al. 1987). The oxidative stress induced by $\mathrm{Cd}$ in a biological system may be due to increased lipid peroxidation, which may be attributed to alterations in the antioxidant defense system (Jemai et al. 2007; Newairy et al. 2007). Interactions between electromagnetic field and Cd are an important epidemiological and a subject of interest of many researchers. In combination with electromagnetic field, $\mathrm{Cd}$ has been shown to increase the level of metallothioneins in the bone marrow and liver of mice (Koterov et al. 1997). Increases in the levels of lipid peroxidation in tissues, accumulation of its end products in biosubstrates, and activation of catalase (CAT) and peroxidase oxidoreductases in blood of test animals have also been shown (Honcharuk et al. 1995). Histological examination revealed differences in tissue reaction suggesting the modification of the repair process due to MF exposure following experimental injury in Cd groups (Hurych et al. 1996). Very little is known about the combined effects of SMF and metals, such as Cd, in mammalian cells or tissues. Interactions between these agents in biological systems are still poorly understood. In the present work we selected combinations of $\mathrm{Cd}$, a toxic metal emanating from industrial and agricultural sources, and MF due to its increasing production and the expanding use of electronic devices in normal life. The aim of the present study was to investigate the combined effects of SMF and Cd on markers of oxidative stress in rat heart and skeletal muscle, and to elucidate a possible variety of additive, synergistic or antagonistic responses.

\section{Materials and Methods}

\section{Animals}

Adult Wistar male rats (SIPHAT, Tunisia), weighing 180-200 g were randomly divided into control rats $(n=6)$, SMF-exposed rats $(n=6)$, Cd-treated group $(n=6)$ and coexposed group to SMF and $\mathrm{Cd}(n=6)$. Animals were housed in group of six in cages at $25^{\circ} \mathrm{C}$, under a $12 / 12 \mathrm{~h}$ light/dark cycle, with free access to water and commercial wash. Animals were cared for under the Tunisian code of practice for the Care and Use of Animals for Scientific Purposes. The experimental protocols were approved by the Faculty Ethics Committee (Faculté des Sciences de Bizerte, Tunisia).

\section{Exposure system}

Lake Shore electromagnets (Lake Shore Cryotronic, Inc., Westerville Ohio, USA) are compact electromagnets suited for many applications such as magnetic resonance demonstrations. Water-cooled coils provide excellent field stability and uniformity when high power is required to achieve the maximum field capability for the electromagnet (Abdelmelek et al. 2006).

\section{SMF exposure}

SMF was measured and standardized in the total floor area of the plexiglas cage $(20 \times 10 \times 20 \mathrm{~cm})$ at $128 \mathrm{mT}$. The two bobbins of the Lake Shore system were separated by $12 \mathrm{~cm}$. Male rats were exposed to the SMF, $1 \mathrm{~h}$ /day (between 9-12 h) during 30 consecutive days. The cage in the Lake Shore system contained two rats for each assay. The control rats were placed under the same conditions without applying the SMF (Abdelmelek et al. 2006).

\section{Cd treatment}

Rats were treated with $\mathrm{Cd}\left(\mathrm{CdCl}_{2}\right)$ in drinking water $(40 \mathrm{mg} /$ 1) for 4 weeks. Co-exposed animals were exposed to SMF $(128 \mathrm{mT})$ for $1 \mathrm{~h}$ /day during 30 consecutive days and received $\mathrm{Cd}$ chloride solution $(40 \mathrm{mg} / \mathrm{l})$ in drinking water.

\section{Tissue preparation}

Following Cd treatment during 4 weeks, control and treated groups were sacrificed and their cardiac and skeletal muscles were immediately harvested. The tissues were homogenized in buffer (Tris $10 \mathrm{mmol} / \mathrm{l}$, EDTA $1 \mathrm{mmol} / \mathrm{l}$, PMSF $1 \mathrm{mmol} / \mathrm{l}$; $\mathrm{pH}=7.5$ ). The homogenates were centrifugated at $600 \times g$ for $10 \mathrm{~min}$ and recentrifugated at $13000 \times g$ for $20 \mathrm{~min}$ at $+4^{\circ} \mathrm{C}$ to obtain a postnuclear homogenate and postmitochondrial supernatant fractions (Ebru and Mesut 2002).

\section{Glutathione peroxidase activity}

The reaction was carried out at $25^{\circ} \mathrm{C}$ in $600 \mu$ of solution containing $100 \mathrm{mmol} / \mathrm{l}$ of potassium phosphate buffer $(\mathrm{pH}$ 7.7), $1 \mathrm{mmol} / \mathrm{l} \mathrm{EDTA,} 0.4 \mathrm{mmol} / \mathrm{l}$ of sodium azide, $2 \mathrm{mmol} / \mathrm{l}$ of glutathione, $0.1 \mathrm{mmol} / \mathrm{l}$ of NADPH, and $0.62 \mathrm{U}$ of glutathione reductase. The activity of glutathione peroxidase (GPx) was assayed by the subsequent oxidation of NADPH at $340 \mathrm{~nm}$ with t-buthyl-hydroperoxide as a substrate (Maral et al. 1977).

\section{CAT activity}

Catalase (CAT) activity was measured at $20^{\circ} \mathrm{C}$ according to Aebi (1984). The homogenate was incubated with ethanol 


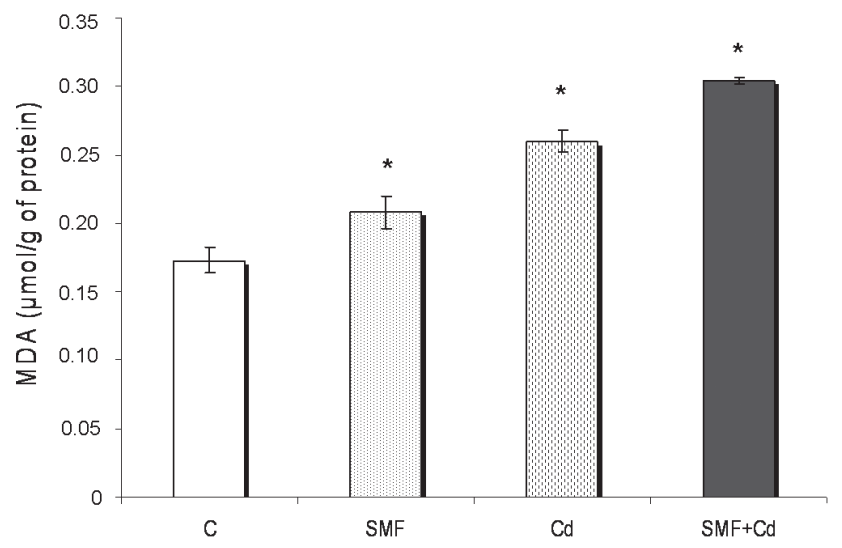

Figure 1. Effect of sub-chronic exposure to SMF and/or cadmium on the MDA level in the heart muscle of rats. C, control; SMF, static magnetic field; Cd, cadmium; MDA, malondialdehyde. Values are means \pm SEM calculated from $n=6$ in each group. ${ }^{*} p<0.05$ compared to control (Student's $t$-test).

(10\%) and Triton (10\%). Activity was assayed at $25^{\circ} \mathrm{C}$ by determining the rate of degradation of $\mathrm{H}_{2} \mathrm{O}_{2}$ at $240 \mathrm{~nm}$ in $10 \mathrm{mmol} / \mathrm{l}$ of potassium phosphate buffer $(\mathrm{pH} \mathrm{7.0)}$. The extinction coefficient of $43.6 \mathrm{mmol} / \mathrm{l} / \mathrm{cm}$ was used for calculation. One unit is defined as $1 \mathrm{pmol}$ of $\mathrm{H}_{2} \mathrm{O}_{2}$ consumed per minute and the specific activity is reported as units per milligram of protein.

\section{Superoxide dismutase activity}

The method described by Paoletti and Macoli (1990) was used for the assay of superoxide dismutase (SOD) activity. This method consists of purely chemical reactions sequence which generates superoxide from molecular oxygen in the presence of EDTA, manganese II chloride and mercaptoethanol.

\section{Malondialdehyde assay}

Lipid peroxidation in the tissues was measured by the TBARS (thiobarbituric acid reacting substance) and was expressed in terms of malondialdehyde (MDA) content (Placer et al. 1966). Sample aliquots were incubated with $10 \%$ trichloroacetic acid and $0.67 \%$ thiobarbituric acid. The mixture was heated on a boiling water bath for $30 \mathrm{~min}$, an equal volume of n-butanol was added, and the final mixture was centrifuged; the organic phase was collected for fluorescence measurements. Samples assayed for MDA contained $1 \mathrm{mmol} / \mathrm{l} \mathrm{BHT}$ (butylated hydroxytoluene) in order to prevent artefactual lipid peroxidation during the boiling step. The absorbance of samples was determined at $532 \mathrm{~nm}$. Results were expressed as $\mu \mathrm{mol} \mathrm{MDA} / g$ protein.

\section{Data presentation and statistical analysis}

Data were analysed using Stat View $512^{+}$software (Abacus concept, Inc.). Means were given with \pm SEM and differences between the controls and treated animals were determined by Student's $t$-test. The level of significance was set at $p<0.05$.

\section{Results}

Effects of SMF and/or Cd on the antioxidant enzymes and MDA concentration in rat heart muscle

The exposure of rats to SMF (128 mT, $1 \mathrm{~h}$ /day during 30 consecutive days) decreased the activities of GPx (1731 \pm 69 vs. $2165 \pm 47, p<0.05)$ and the CuZn-SOD $(10.76 \pm$ 0.26 vs. $13.53 \pm 0.57, p<0.05$ ) (Table 1). Moreover, subchronic exposure to SMF increased the MDA concentration $(0.208 \pm 0.012$ vs. $0.173 \pm 0.009, p<0.05)$ (Fig. 1$)$. However, Cd treatment $\left(\mathrm{CdCl}_{2}, 40 \mathrm{mg} / \mathrm{l}\right.$, per os) during 4 weeks decreased the activity of CuZn-SOD $(10.63 \pm 0.6$ vs. $13.53 \pm 0.57, p<0.05$ ) (Table 1 ) and increased MDA concentration $(0.260 \pm 0.008$ vs. $0.173 \pm 0.009, p<0.05)$ (Fig. 1). The combined effect of SMF (128 mT, 1 day during 30 consecutive days) and Cd ( $40 \mathrm{mg} / \mathrm{l}$, per os) disrupt the antioxidant enzymes activity in rat cardiac muscles (Table 1). Moreover, we noted a huge increase in MDA concentration $(0.304 \pm 0.003$ vs. $0.173 \pm 0.009, p<0.05)$ compared to control group (Fig. 1).

Table 1. Effect of sub-chronic exposure to SMF and/or cadmium in the antioxidant enzymes activity in rat heart muscle

\begin{tabular}{|l|c|c|c|c|}
\hline & $\begin{array}{c}\text { GPx } \\
(\mathrm{U} / \mathrm{mg} \mathrm{pt})\end{array}$ & $\begin{array}{c}\text { CAT } \\
(\mathrm{U} / \mathrm{mg} \mathrm{pt})\end{array}$ & $\begin{array}{c}\text { CuZn-SOD } \\
(\mathrm{U} / \mathrm{mg} \mathrm{pt})\end{array}$ & $\begin{array}{c}\text { Mn-SOD } \\
(\mathrm{U} / \mathrm{mg} \mathrm{pt})\end{array}$ \\
\hline C & $2165 \pm 47$ & $40.86 \pm 3.46$ & $13.53 \pm 0.57$ & $0.57 \pm 0.07$ \\
\hline SMF & $1731 \pm 69^{*}$ & $44.67 \pm 3.36$ & $10.76 \pm 0.26^{*}$ & $0.41 \pm 0.1$ \\
\hline Cd & $1825 \pm 232$ & $36.13 \pm 3.92$ & $10.63 \pm 0.6^{*}$ & $0.48 \pm 0.12$ \\
\hline SMF+Cd & $1664 \pm 52^{*}$ & $38.15 \pm 2.83$ & $10.24 \pm 0.19^{\star}$ & $0.39 \pm 0.07^{\star}$ \\
\hline
\end{tabular}

Data represent the means \pm SEM of 6 animals per group. C, control; SMF, static magnetic field; Cd, cadmium; GPx, glutathione peroxidise; CAT, catalase; SOD, superoxide dismutase; $\mathrm{pt}$, protein; ${ }^{\star} p<0.05$, compared to control. 
Effects of SMF and/or Cd on the antioxidant enzymes and MDA concentration in rat skeletal muscle

Sub-chronic exposure to SMF failed to alter the antioxidant enzymes activity (Table 2). Moreover, the MDA concentration remained unchanged in SMF-exposed rats (Fig. 2). However, $\mathrm{Cd}$ administration $\left(\mathrm{CdCl}_{2}, 40 \mathrm{mg} / \mathrm{l}\right.$, per os) during 4 weeks decreased the activities of CAT $(2.8 \pm 0.45 v s .4 .2 \pm 041, p<$ 0.05 ) (Table 2) and increased MDA concentration $(0.120 \pm$ 0.015 vs. $0.095 \pm 0.01, p<0.05$ ) (Fig. 2). The combined effect of SMF (128 mT, $1 \mathrm{~h} /$ day during 30 consecutive days) and Cd (40 mg/l, per os) disrupt the antioxidant enzymes activity in rat skeletal muscles (Table 2). Moreover, we noted a huge increase in MDA concentration in the skeletal muscle $(0.152$ \pm 0.009 vs. $0.095 \pm 0.01, p<0.05)$ compared to control group (Fig. 2).

\section{Discussion}

In the present paper we examined the effects of combinations of two environmental pollutants: Cd and SMFs. In order to estimate the involvement of the SMF and/or Cd-caused disorders in the antioxidant barrier and enhance lipid peroxidation in rat heart and skeletal muscle. Large research activity has risen around the mechanisms of interaction between MFs and biological systems. MF may interfere with chemical reactions involving reactive oxygen species (ROS), thus facilitating oxidative damages in living cells (Di Loreto et al. 2009). On the other hand, oxidative stress has been recognized to play a pivotal role in the mechanisms of toxic action of numerous xenobiotics, including Cd (Valko et al. 2006). The results presented in this manuscript showed that the independent effect of sub-chronic exposure to SMF or Cd induced a low level of oxidative stress in rat muscle tissues, but the combined effect altered significantly the antioxidant enzymatic capacity and induced lipid peroxidation in both skeletal and cardiac muscle. Previously, in our laboratory Abdelmelek and co-workers (2006) showed that SMF affect noradrenergic systems in rat's gastrocnemius muscles. Such an increase could possibly explain the enhanced activity of

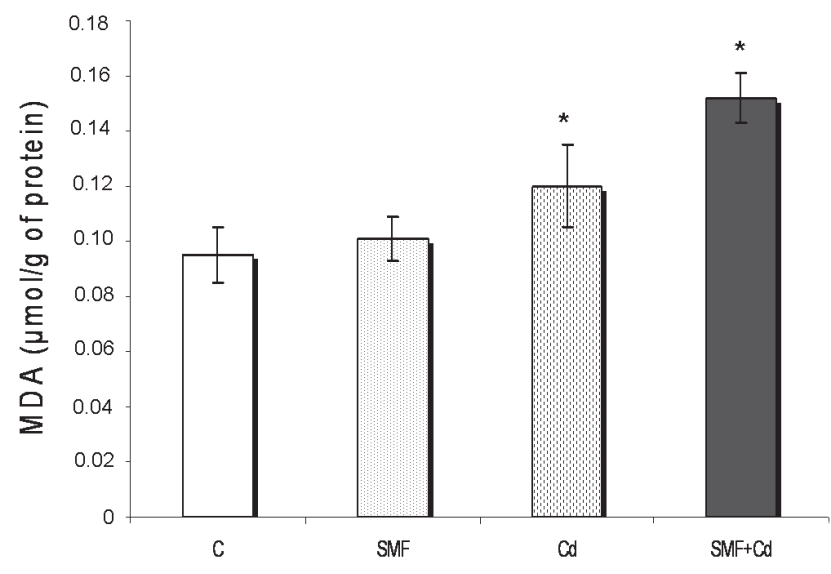

Figure 2. Effect of sub-chronic exposure to SMF and/or cadmium on the MDA level in the skeletal muscle of rats. C, control; SMF, static magnetic field; $\mathrm{Cd}$, cadmium; MDA, malondialdehyde. Values are means \pm SEM calculated from $n=6$ in each group. ${ }^{\star} p<0.05$ compared to control (Student's $t$-test).

sympathetic nervous system, indicating a stress induced by sub-acute exposure to SMF. Under the present experimental conditions it has been observed that sub-chronic exposure to SMF decline the GPx and CuZn-SOD activity, which would lead to stimulation of MDA production in rat cardiac muscle. MDA is the main product of lipid peroxidation and it has been strongly correlated with the oxidative damage in tissues (Del Rio et al. 2005). In the basis of experimental results this study indicates that SMF could influence the cardiac antioxidant activity and might act as an oxidative stressor. Hashih and co-workers (2008) also reported that there is a relation between the exposure to SMF and the oxidative stress through distressing redox balance leading to physiological disturbances.

Our data showed a reduction in cardiac SOD activity in the Cd-exposed animals. Since SOD is a metallo-enzyme; reduction in its activity may be attributed to dysfunctional conformational change which may be due to the replacement of $\mathrm{Zn}^{2+}$ present in SOD by Cd leading to loss of enzymatic activity (Kofod et al. 1991; Casalino et al. 2002). Like SOD,

Table 2. Effect of sub-chronic exposure to SMF and/or cadmium in the antioxidant enzymes activity in rat skeletal muscle

\begin{tabular}{|l|c|c|c|c|}
\hline & $\begin{array}{c}\text { GPx } \\
(\mathrm{U} / \mathrm{mg} \mathrm{pt})\end{array}$ & $\begin{array}{c}\text { CAT } \\
(\mathrm{U} / \mathrm{mg} \mathrm{pt})\end{array}$ & $\begin{array}{c}\text { CuZn-SOD } \\
(\mathrm{U} / \mathrm{mg} \mathrm{pt})\end{array}$ & $\begin{array}{c}\text { Mn-SOD } \\
(\mathrm{U} / \mathrm{mg} \mathrm{pt})\end{array}$ \\
\hline C & $324 \pm 20$ & $4.2 \pm 041$ & $6.85 \pm 0.39$ & $1.45 \pm 0.07$ \\
\hline SMF & $317 \pm 50$ & $3.39 \pm 0.79$ & $7.53 \pm 0.4$ & $1.41 \pm 0.06$ \\
\hline Sd & $278 \pm 31$ & $2.8 \pm 0.45^{*}$ & $6.76 \pm 0.29$ & $1.36 \pm 0.15$ \\
\hline
\end{tabular}

Data represent the means \pm SEM of 6 animals per group. C, control; SMF, static magnetic field; Cd, cadmium; GPx, glutathione peroxidise; CAT, catalase; SOD, superoxide dismutase; $\mathrm{pt}$, protein; ${ }^{*} p<0.05$, compared to control. 
another antioxidant enzyme, CAT also experienced significant reduction in activity in the skeletal muscle of the Cd-exposed animals. The reduction of antioxidant enzymes activity was associated with MDA increase in both muscle structures. These results suggest that $\mathrm{Cd}$ intoxication induced oxidative stress in rat muscle tissues. In accordance with this view, several studies found that skeletal muscle was a poor $\mathrm{Cd}$-accumulating tissue and this metal mediated oxidative damage in muscle tissues (Yano and Marcondes 2005; Gonzalez et al. 2006; Manna et al. 2008). Although Cd does not generate free radials directly (Lloyd et al. 1998; Valko et al. 2006), it can do so indirectly by facilitating increases in lipid peroxidation (Filipic and Hei 2004), decreases in intracellular glutathione content, decreases in activities of cellular antioxidant enzymes including SOD, peroxidase and CAT, (Hussain et al. 1987; Waisberg et al. 2003), and increases in iron and copper concentrations (Koizumi et al. 1992; Casalino et al. 1997), all of which can lead to increasing levels of ROS.

At present, a clear correlation between co-exposure to $\mathrm{MF}$ and $\mathrm{Cd}$ and any adverse health effect is, however, not sufficiently established. In this study, changes in oxidative stress parameters in the heart and skeletal muscle of rats coexposed to SMF and Cd were more advanced than at separate exposure. This effect may result from an independent effect of SMF and Cd and also from their interaction such as changes in metal accumulation and content of essential elements like $\mathrm{Cu}, \mathrm{Zn}$ and Fe. Recently, in our laboratory Amara et al. (2007) showed that SMF exposure decreased the labile zinc fraction and induced deficiency of this element in THP1 cells. In this context, SMF can react with $\mathrm{Cd}$ and transition metals, highly present in skeletal and cardiac muscle, to produce the extremely reactive hydroxyl radicals that can easily altered anti-oxidative enzymatic protection. The accumulations of hydrogen peroxide could develop oxidative attack and could induce severe oxidative stress in heart and skeletal muscle. These disturbances of antioxidant enzymatic capacity was followed by a huge increase of MDA levels in both muscle tissues of co-exposed rats as compared with control animals, indicating an extensive tissue lipid peroxidation. The co-exposure to SMF and Cd may act as a risk factor for the occurrence of the depletion of antioxidant enzymatic capacity and lipid peroxidation in rat heart and skeletal muscle. Recently, Youn et al. (2005) suggest that a combination of $\mathrm{Cd}$ and radiation had an additive effect on the frequency of micronuclei formation. In addition, a synergistic increase in enzyme activities of lactate dehydrogenase, alkaline phosphatase, and acid phosphatase in Wistar rats under combined action of Cd and radiation was also reported (Salovsky et al. 1993). I the view of experimental results and theoretical analysis, it can be suggested that MF could modulate $\mathrm{Cd}$ toxicity, thus favouring the onset and progression of several oxidative stress and tissues damage. The increase of oxidative stress level in muscle tissues appear to be consistent with a mechanism involving increases in ROS production following co-exposure to SMF and Cd. However, the underlying mechanisms that could be responsible for such effects are still not clearly understood.

Based on the results of the present study it can be concluded that SMF or Cd can lead to the depletion of antioxidant enzymatic system and lipid peroxidation in rat heart and skeletal muscle. The most important and new finding of the study is revealing that oxidative stress damage at coexposure to SMF and Cd may be more markedly advanced than at separate exposure.

\section{References}

Abdelmelek H., Molnar A., Servais S., Cottet-Emard J. M., Pequignot J. M., Favier R., Sakly M. (2006): Muscle HSP72 and norepinephrine response to static magnetic field in rat. J. Neural. Transm. 113, 821-827; doi:10.1007/s00702-005-0364-7

Aebi H. (1984): Catalase in vitro. Methods Enzymol. 105, 121-126; doi:10.1016/S0076-6879(84)05016-3

Amara S., Douki T., Ravanat J. L., Garrel C., Guiraud P., Favier A., Sakly M., Ben Rhouma K., Abdelmelek H. (2007): Influence of a static magnetic field $(250 \mathrm{mT})$ on the antioxidant response and DNA integrity in THP1 cells. Phys. Med. Biol. 52, 889-898; doi:10.1088/0031-9155/52/4/002

Boguszewska A., Pasternak K. (2004): Cadmium-influence on biochemical processes of the human organism. Ann. Univ. Mariae. Curie. Sklodowska 59, 519-523

Casalino E., Sblano C., Landriscina C. (1997): Enzyme activity alteration by cadmium administration to rats: the possibility of iron involvement in lipid peroxidation. Arch. Biochem. Biophys. 346, 171-179; doi:10.1006/ abbi.1997.0197

Casalino E., Calzaretti G., Sblano C., Landriscina C. (2002): Molecular inhibitory mechanisms of antioxidant enzymes in rat liver and kidney by cadmium. Toxicology 179, 37-50; doi:10.1016/S0300-483X(02)00245-7

Davanipour Z., Tseng C. C., Lee P. J., Sobel E. (2007): A casecontrol study of occupational magnetic field exposure and Alzheimer's disease: results from the California Alzheimer's Disease Diagnosis and Treatment Centers. BMC. Neurol. 9, 7-13

Del Rio D., Stewart A. J., Pellegrini N. (2005): A review of recent studies on malondialdehyde as toxic molecule and biological markers of oxidative stress. Nutr. Metabol. Cardiovasc. Dis. 15, 316-328; doi:10.1016/j.numecd.2005.05.003

Di Loreto D. S., Falone S., Caracciolo V., Sebastiani P., D'Alessandro A., Mirabilio A., Zimmitti V., Amicarelli F. (2009): Fifty hertz extremely low-frequency magnetic field exposure elicits redox and trophic response in rat-cortical neurons. J. Cell. Physiol. 219, 334-343; doi:10.1002/jcp.21674

Ebru B., Mesut A. (2002): The effect of long-term supplemental dietary cadmium on lipid peroxidation and the antioxidant system in the liver and kidneys of rabbits. Turk. J. Vet. Anim. Sci. 26, 1055-1060 
Filipic M., Hei T. K. (2004): Mutagenicity of cadmium in mammalian cells: implication of oxidative DNA damage. Mutat. Res. 546, 81-91; doi:10.1016/j.mrfmmm.2003.11.006

Gonzalez P., Baudrimont M., Boudou A., Bourdineaud J. P. (2006): Comparative effects of direct cadmium contamination on gene expression in gills, liver, skeletal muscles and brain of the zebrafish (Danio rerio). Biometals 19, 225-235; doi:10.1007/s10534-005-5670-x

Håkansson N., Gustavsson P., Sastre A., Floderus B. (2003): Occupational exposure to extremely low frequency magnetic fields and mortality from cardiovascular disease. Am J. Epidemiol. 158, 534-542; doi:10.1093/aje/kwg197

Hashish A. H., El-Missiry M. A., Abdelkader H. I., Abou-Saleh R. H. (2008): Assessement of biological changes of continuous whole body exposure to static magnetic field and extremely low frequency electromagnetic fields in mice. Ecotoxicol. Environ. Saf. 71, 895-902; doi:10.1016/ j.ecoenv.2007.10.002

Honcharuk Ie. H., Bardov V. H., Kartysh A. P, Iavorovs'yi Korshun M. M., Verpivs'kyi O. M. (1995): An experimental study of the mechanism of the combined action on the body of ionizing radiation, pesticides, nitrates and lead and cadmium salts. Lik. Sprava 6, 7-12 (in Ukrainian)

Hurych J., Mirejovska E., Holusa R., Bubenikova D. (1996): Effects of magnetic field exposure on the development of lung fibrosis elicited by industrial pollutants. Toxicol. Lett. 88, 305-311 doi:10.1016/0378-4274(96)03754-X

Hussain T., Shukla G. S., Chandra S. V. (1987): Effects of cadmium on superoxide dismutase and lipid peroxidation in liver and kidney of growing rats: in vivo and in vitro studies. Pharmacol. Toxicol. 60, 355-358; doi:10.1111/j.16000773.1987.tb01526.x

Jemai H., Messaoudi I., Chaouch A., Kerkeni A. (2007): Protective effect of zinc supplementation on blood antioxidant defense system in rats exposed to cadmium. J. Trace Elem. Med. Biol. 21, 269-273; doi:10.1016/j.jtemb.2007.08.001

Kofod P., Baurer R., Danielsen E., Larsen E., Bjerrum M. J. (1991): 113Cd-NMR investigation of a cadmium-substitution copper, zinc-containing superoxide dismutase from yeast. Eur. J. Biochem. 198, 607-611; doi:10.1111/j.1432 1033.1991.tb16057.x

Koizumi T., Li Z. G., Tatsumoto H. (1992): DNA damaging activity of cadmium in Leydig cells, a target cell population for cadmium carcinogenesis in the rat testis. Toxicol. Lett. 63, 211-220; doi:10.1016/0378-4274(92)90013-A

Koterov A. N., Trebenok Z.A., Pushkareva N.B., Nikol'skii A.V. (1997): The diverse effects of the combined action of cadmium chloride and ionizing radiation on the content of metallothioneins in mouse bone marrow and liver. Radiats. Biol. Radioecol. 37, 196-201 (in Russian)

Lloyd D. R., Carmichael P. L., Phillips D. H. (1998): Comparison of the formation of 8-hydroxy-2'-deoxyguanosine and single- and double-strand breaks in DNA mediated by fenton reactions. Chem. Res. Toxicol. 11, 420-427; doi:10.1021/tx9701561

Loomis D. P., Savitz D. A. (1990): Mortality from brain cancer and leukaemia among electrical workers. Br. J. Ind. Med. 47, 633-638
Manna P., Sinha M., Sil P. C. (2008): Amelioration of cadmiuminduced cardiac impairment by taurine. Chem. Biol. Interact. 174, 88-97; doi:10.1016/j.cbi.2008.05.005

Maral J., Puget K., Michelson A. M. (1977): Comparative study of superoxide dismutase, catalase and glutathione peroxidase levels in erythrocytes of different animals. Biochem. Biophys. Res. Commun. 15, 1525-1535; doi:10.1016/ S0006-291X(77)80151-4

Newairy A. A., El-Sharaky A. S., Badreldeen M. M., Eweda S. M., Sheweita S. A. (2007): The hepatoprotective effects of selenium against cadmium toxicity in rats. Toxicology 242, 23-30; doi:10.1016/j.tox.2007.09.001

Okano H. (2008): Effects of static magnetic fields in biology: role of free radicals. Front Biosci. 13, 6106-6125; doi:10.2741/3141

Paoletti F., Mocali A. (1990): Determination of superoxide dismutase activity by purely chemical system based on NADPH oxidation. Meth. Enzymol. 186, 209-220; doi:10.1016/0076-6879(90)86110-H

Placer Z. A., Cushman L. L., Johnson B. C. (1966): Estimation of product of lipid peroxidation (Malonyldialdehyde) in biochemical systems. Anal. Biochem. 16, 359-364; doi:10.1016/0003-2697(66)90167-9

Renugadevi J., Prabu S. M. (2009): Cadmium-induced hepatotoxicity in rats and the protective effect of naringenin. Exp. Toxicol. Pathol. (in press); doi:10.1016/j.etp.2009.03.010

Roccheri M. C., Agnello M., Bonaventura R., Matranga V. (2004): Cadmium induced the expression of specific stress proteins in sea urchin embryos. Biochem. Biophys. Res. Commun. 321, 80-87; doi:10.1016/ j.bbrc.2004.06.108

Salovsky P., Shopova V., Dancheva V., Marev R., Pandurska A. (1993): Enhancement of the pneumotoxic effect of cadmium acetate by ionizing radiation in the rat. Environ. Health Perspect. 101 (Suppl. 2), 269-274; doi:10.2307/3431399

Valko M., Rhodes C. J., Moncol J., Izakovic M., Mazur M. (2006): Free radicals, metals and antioxidants in oxidative stress-induced cancer, Chem. Biol. Interact. 160, 1-40; doi:10.1016/j.cbi.2005.12.009

Waisberg M., Joseph P., Hale B., Beyersmann D. (2003): Molecular and cellular mechanisms of cadmium carcinogenesis. Toxicology 192, 95-117; doi:10.1016/S0300483X(03)00305-6

Wertheimer N., Leeper E. (1979): Electrical wiring configurations and childhood cancer. Am. J. Epidemiol. 109, 273-284

Yano C. L., Marcondes M. C. (2005): Cadmium chloride-induced oxidative stress in skeletal muscle cells in vitro. Free Radic. Biol. Med. 39, 378-384; doi:10.1016/j.freeradbio med.2005.07.001

Youn C. K., Kim S. H., Lee D. Y., Song S. H., Chang I. Y., Hyun J. W., Chung M. H., You H. J. (2005): Cadmium downregulates human OGG1 through suppression of Sp1 activity. J. Biol. Chem. 280, 25185-25195; doi:10.1074/jbc. M412793200

Received: April 17, 2009

Final version accepted: July 1, 2009 